\title{
Correction to: Catabolism of L-rhamnose in $A$. nidulans proceeds via the non-phosphorylated pathway and is glucose repressed by a CreA-independent mechanism
}

\author{
Andrew P. MacCabe ${ }^{1}$, Elpinickie I. Ninou ${ }^{1,2}$, Ester Pardo $^{1,3}$ and Margarita Orejas ${ }^{1 *}$ (B)
}

\section{Correction to: Microb Cell Fact (2020) 19:188 https://doi.org/10.1186/s12934-020-01443}

Following publication of the original article [1], the authors identified an error in funding section. The correct funding note is given in this Correction article.

Funding: This work was supported by the Spanish Ministerio de Ciencia e Innovación/FEDER and Ministerio de Economía y Competitividad/FEDER (Grant Numbers AGL2011-29,925 and AGL2015-66,131-C2-2-R, respectively). The original article has been revised.

\section{Reference}

1. MacCabe AP, Ninou El, Pardo E, Orejas M. Catabolism of L-rhamnose in A. nidulans proceeds via the non-phosphorylated pathway and is glucose repressed by a CreA-independent mechanism. Microb Cell Fact. 2020;19:188. https://doi.org/10.1186/s12934-020-01443.

\section{Publisher's Note}

Springer Nature remains neutral with regard to jurisdictional claims in published maps and institutional affiliations.

\begin{abstract}
Author details
${ }^{1}$ Instituto de Agroquímica y Tecnología de Alimentos (IATA), Consejo Superior de Investigaciones Científcas (CSIC), c/Catedrático Agustín Escardino Benlloch 7, 46980 Paterna, Valencia, Spain. ${ }^{2}$ Present Address: Center for Basic Research, Biomedical Research Foundation, Academy of Athens (BRFAA), 4 Soranou Ephessiou Street, 11527 Athens, Greece. ${ }^{3}$ Present Address: ADM Biopolis, Parque Científco Universidad de Valencia, c/Catedrático Agustín Escardino Benlloch 9, 46980 Paterna, Valencia, Spain.
\end{abstract}

Published online: 07 December 2021 permits use, sharing, adaptation, distribution and reproduction in any medium or format, as long as you give appropriate credit to the original author(s) and the source, provide a link to the Creative Commons licence, and indicate if changes were made. The images or other third party material in this article are included in the article's Creative Commons licence, unless indicated otherwise in a credit line to the material. If material is not included in the article's Creative Commons licence and your intended use is not permitted by statutory regulation or exceeds the permitted use, you will need to obtain permission directly from the copyright holder. To view a copy of this licence, visit http://creativecommons.org/licenses/by/4.0/. The Creative Commons Public Domain Dedication waiver (http://creativeco mmons.org/publicdomain/zero/1.0/) applies to the data made available in this article, unless otherwise stated in a credit line to the data. 